\title{
Global Poverty and the Politics of Good Intentions
}

\author{
Osgoode Reader
}

Sundhya Pahuja ${ }^{1}$

\section{Introduction}

In the West, the terrain of a great deal of public debate around poverty is largely delimited by two figurations; activism and expertise. For the activist, fighting global poverty has become the moral cause of a new generation, inspiring rock songs and wrist bands, and legions of celebrities for whom charity is the new accessory. For the expert, development is a technical project in which a body of knowledge, typically marshalled through the disciplinary lens of economics, is formulated for and applied to the problems of the 'developing' world, and then measured in a more or less 'scientific' way. ${ }^{2}$

Despite their differences in sensibility, these figurations share two crucial things. First, development is the only problematic within which the question of material wellbeing and global wealth distribution can be addressed. And second, both expert and activist view international law as an instrumental means by which poverty may be addressed, but which is intrinsically secondary, or epiphenomenal to the causes of poverty. This consensus takes form in and finds application through international institutional efforts directed toward global poverty reduction. It remains resilient

\footnotetext{
${ }^{1}$ Associate Professor, Melbourne Law School, Director, Law and Development Research Programme, Institute for International Law and the Humanities, University of Melbourne.s.pahuja@unimelb.edu.au ${ }^{2}$ On the turn to indicators, see S Merry, 'Measuring the World: Indicators, Human Rights and Global Governance' (August 24, 2009) www.nyu.edu/ipk/files/docs/events/merry-measuring.doc; and B Fine, 'Economics Imperialism and the New Development Economics as Kuhnian Paradigm Shift?' (2002) 30 World Development 2057.
} 
despite what are arguably the manifest failures of the development project over the past 70 years.

In the face of this consensus, my thesis can be simply stated. In essence, I argue that international institutional attempts to address poverty (re) iterated in the idiom of development, are likely to make the problem worse rather than better. The international development project can be understood as a continuation of the benevolence of empire' in which interventions were conducted 'in the service of enabling the conditions of modernity to emerge, in the belief that these would serve better the interests and well-being of humanity.' The point of the characterisation is not to judge the sincerity of the 'good intentions', but to draw attention to the fact that 'what remains indisputable is the authority with which such a gesture can be made, the vantage point from which it asserts itself' (emphasis added). ${ }^{3}$

Key to the production and maintenance of that authority are the intimacies between development and international law. International law's effect in the world hinges largely on its capacity to authorise, including the practices it authorises under the rubric of development. But development and international law also share a structural homology, such that even as authority is vested upwards into the 'international community', responsibility is vested downwards into the nation-state. The combination of the structural homology between international law and development with development's capture of the way poverty is understood and addressed within international law and institutions, means that even as the international community takes responsibility 'for' global poverty (whether sincerely or not) it is not

\footnotetext{
${ }^{3}$ N Shaikh, 'Interrogating Charity and the Benevolence of Empire' (2007) 50 Development 83, 85.
} 
accountable for actions taken in the name of that 'duty'. The unaccountability persists even as that sphere of action expands, in ways which often work against the interests of the world's poorest people. The result is a frame of reference in which selfinterested and impoverishing behaviour by the West is understood as altruism toward the rest, or as being in the interests of poor states. ${ }^{4}$

Whether international law can be rehabilitated from this complicity or not, remains an open question, but the argument calls us to rethink the development promise in a profound way. At the very least, it calls on us to be wary of the politics of good intentions, which continue both to shape contemporary international approaches to global poverty, and to serve as their measure.

\section{International law, Development and Poverty Alleviation}

Alongside securing peace, security, and international order, the alleviation of poverty has been an explicit goal of contemporary international law since its institutional reinauguration in the 1940s. One of the four explicit aims in the Preamble to the United Nations ('UN') Charter, for example, was the commitment to 'the [promotion] of social progress and better standards of life in larger freedom, ${ }^{5}$ We can think too of the motto of the World Bank, 'Our dream is a world free of poverty' as a paradigmatic example. ${ }^{6}$ The same stated purpose applies to many international

\footnotetext{
${ }^{4}$ The effect of this combination is to allow the self-interest of rich countries in the form of market access and cheap primary commodities which conditionality effects, to be equated with altruism in the name of development. This recurring equation of altruism and self-interest is facilitated by the development story. See also G Rist, The History of Development: From Western Origins to Global Faith (London, Zed Books, 1997) 90-91.

${ }^{5}$ Charter of the United Nations, Preamble www.un.org/en/documents/charter/preamble.shtml. ${ }^{6}$ See for example, the statement set in marble at the front entrance to the World Bank building: 'Our dream is a world free of poverty'; 'Working for a world free of poverty' as part of the World Bank logo, as on its homepage www.worldbank.org; or the recent World Bank publication, Our Dream: A World Free of Poverty (New York, World Bank and Oxford University Press, 2010).
} 
institutions, including the FAO, and the UNDP, as well as regional development banks such as the Asian development bank. ${ }^{7}$

More people and institutions are reiterating this purpose, and more frequently, than ever before. One recent example is UN Secretary General Ban Ki-moon's address to the G20 summit in Toronto to 'stress[...] the concerns of the world's most vulnerable and the need for everyone to step up efforts to eradicate poverty... ${ }^{8}$ But since the wave of decolonisation in the 1950s and 1960s, the modern concept of development has been both central to the way the question of material need and distribution plays out internationally, and deeply intertwined with the history of contemporary international law.

This dominance remains true to the present day, such that when we talk about the persistence of global poverty, the solution is still always development. The efforts of the world to eradicate extreme poverty and hunger, for example, to empower women, to increase primary education, to reduce child and infant mortality, and to improve maternal health are declared to be the millennium development goals. ${ }^{9}$ Trade negotiation rounds which purport to focus on poor countries are labelled 'development rounds', and the way we turn to the problem of environmental degradation is sustainable development. ${ }^{10}$ Even international military interventions have been recast

\footnotetext{
${ }^{7}$ The objective of poverty reduction ('reducing poverty' or 'reducing hunger') features in each of these institutions' self-descriptions: Asian Development Bank, 'About ADB' (2011) www.adb.org/About/; Food and Agriculture Organization of the United Nations, 'About FAO' (2011)

www.fao.org/about/en/; and United Nations Development Programme, 'About UNDP' (2010) www.undp.org/about/.

${ }^{8}$ UN News Centre, 'UN Brings Focus on Plight of World's Vulnerable to G20 Summit in Canada' (25 June 2010) www.un.org/apps/news/story.asp?NewsID=35158\&Cr=MDG\&Cr1.

${ }^{9}$ United Nations, 'Millennium Development Goals' (2010) www.un.org/millenniumgoals/.

${ }^{10}$ Indeed, the first line of response to climate change has been a series of high level reports on the economics of climate change, see eg. N Stern, 'Stern Review: The Economics of Climate Change' (2006) www.hm-treasury.gov.uk/stern review report.htm; R Garnaut, 'The Garnaut Review 2011:
} 
statistically as development problems; money spent on security and post-war reconstruction in Iraq and Afghanistan for example, is now being counted as 'development' spending. ${ }^{11}$ This shorthand is also indiscriminate, implicitly uniting diverse identities as swathes of nation-states are grouped together as 'developing', not only in the face of obvious differences between their societies, but equally whether the development project be moribund (like Sudan) or seems to have been successful (as in Singapore).

This equivalence has been remarkably resilient, even in the face of its poor record. For despite more than sixty years of 'development', the proliferation of a huge international bureaucracy, and thousands of NGOs dedicated to bringing about the end of poverty, the gains have been modest, at best. Using the institutions' own terms, which hinge on monetary, income based measures of poverty, recent World Bank statistics suggest that half the world's people live on less than the official poverty line of $\$ 2.50$ per day, and many survive on far less than that. ${ }^{12}$

The World Bank's own statistics regarding improvements on various indicators show only marginal gains. If the clear decline in income poverty in China is excluded, then the percentage of people living below the poverty line in the rest of the world has barely declined over the past three decades. ${ }^{13}$ This failure is especially marked given the world economy's twenty-fold increase over the twentieth century. Over this time,

Australia in the Global Response to Climate Change' (2011) http://www.garnautreview.org.au/update2011/garnaut-review-2011/garnaut-review-2011.pdf. This is another performance of the 'economics imperialism' described in B Fine, 'Vicissitudes of Economics Imperialism' (2008) 66 Review of Social Economy 235.

${ }^{11}$ A Muscara, 'Military Intervention Trumping Humanitarian Aid' (IPS, February 10 2011) http://ipsnews.net/news.asp?idnews=54437; Department for International Development, 'Department for International Development Draft Structural Reform Plan' (27 July 2010) www.dfid.gov.uk/Documents/DFID_SRP.pdf.

${ }^{12}$ World Bank, 'Indicators' (2011) http://data.worldbank.org/indicator.

${ }^{13}$ Ibid. 
not only has the world become much richer, but a colossal international bureaucracy has proliferated, specifically charged with the task of alleviating poverty. Easterley estimates that over $\$ 2.3$ trillion has been spent on foreign aid alone over the last five decades. $^{14}$

Over the same period, inequality has also increased significantly. Just on an individualised level, the world's richest 450 individual people possess more wealth than the poorest 415 million people combined. In regional terms, the ratio of per capita income of Europe to Africa in 1960 was 30:1. By 2005, it had swollen to 40:1. ${ }^{15}$ Along these lines, in his recent book Farewell to Alms, economic historian Gregory Clark suggests that in the present moment, there live on this earth today both the poorest and the richest people who have ever lived. ${ }^{16}$ Even if Clark is only partly right, this is a dark fact. In combination with the statistics above, it is a telling indictment of our collective failure to address the poverty-related suffering of most of the people in the world. In addition to this failure, those states which have raised the standard of living of their general populations have almost invariably done so by specifically ignoring international developmental orthodoxies. ${ }^{17}$

Added to the mix of these puzzlingly small gains in poverty reduction, the ambiguous outcomes of orthodox approaches to development and the growth of inequality, it is now unavoidably apparent that we are also using too many of the planet's resources,

\footnotetext{
${ }^{14}$ William Easterley, The White Man's Burden: Why the West's Efforts to Aid the Rest Have Done So Much Ill and So Little Good (Oxford, Oxford University Press, 2007) 4.

${ }^{15}$ See generally, United Nations Development Policy and Analysis Division, 'World Economic and Social Survey 2010: Retooling Global Development, Chapter I Growth and Development Trends, 1960-2005' (2010) www.un.org/en/development/desa/policy/wess/wess current/2010wess chapter1.pdf.

${ }^{16}$ G Clark, A Farewell to Alms: A Brief Economic History of the World (Princeton, Princeton University Press, 2007) 3.

${ }^{17}$ H Chang, Bad Samaritans: The Myth of Free Trade and the Secret History of Capitalism (New York, Bloomsbury Press, 2008).
} 
and too quickly. This is true not only in terms of carbon emissions, but also in relation to extreme biodiversity loss, the despoiling of the oceans and in the introduction of an escalating array of chemical pollutants in the atmosphere, soil and waterways. I return to this problem and what it might imply for the development project below, but let us turn first to the question of development as a proxy for the question of material wellbeing.

\section{The Difficulty with Development as Proxy}

One potential response to the observation that 'development' has become the universal frame of international approaches to poverty reduction, is that development constitutes merely a word, or place-marker. What we intend when we use it, it might be said, is to indicate a general encapsulation of people improving their standard of living: what is important is the idea of getting better, or progress, that it implies. However, as Carl Schmitt reminded us in his 1929 essay, The Age of Neutralisations and Depoliticisations, concepts must be understood in terms of their concrete political existence. ${ }^{18}$ Development is not just a neutral place marker, and as an idea, it does not simply mean a general improvement of any kind in people's quality of life. Development has a very particular history, which is both a legacy of imperialism and intimately intertwined with the history of contemporary international law. It is not just a word; it is a specific way of knowing the world that is both discourse and institutional machinery.

Decolonisation was crucial to the emergence of the concept of development as we now know it. The end of the war, the success of independence struggles and the

\footnotetext{
${ }^{18}$ C Schmitt, 'The Age of Neutralizations and Depolitizations (1929)' trans J McCormick (1993) 96 Telos 119.
} 
fatigue of Empire meant that former colonies were increasingly decolonising. The universalisation of (European) public international law during the imperial period meant that the colonies could only decolonise through self-determination as nationstates (and that too within former colonial boundaries, expressed in the doctrine of uti possedetis). And yet even as nation-statehood channelled the results of decolonisation through its monopoly over legal personality, successful struggles for independence still confronted the identity of the international 'community' with difference. ${ }^{19}$ During and after the period of decolonisation, what we might call the changing complexion of the international community potentially exposed international law's universal coverage as grounded in the geography of empire, and its claim to universality as founded in a hierarchy secured historically by racial difference. ${ }^{20}$ It was modern development discourse that provided a way to maintain the universal claim and putative objectivity of international law in the face of these differences.

This maintenance was facilitated by securing the values being put forth as universal, in a new hierarchy anchored by the freshly minted, and ostensibly scientific, concept of Gross National Product. The concept of Gross National Product (GNP or GDP) was invented in the 1950 s around the same time as concept of development. ${ }^{21}$ As a number, it provided scientific ratification for the United States in its position as the world's most powerful nation. It also replaced race as the measure of superiority between peoples in ways that the holocaust had made unpalatable, even to the (then

\footnotetext{
${ }^{19} \mathrm{~S}$ Pahuja, 'Decolonisation and the Eventness of International Law' in F Johns, R Joyce and S Pahuja (eds), Events: The Force of International Law (Oxon, Routledge, 2011).

${ }^{20} \mathrm{~S}$ Pahuja, Decolonizing International Law: Development, Economic Growth and the Politics of Universality (Cambridge, Cambridge University Press, forthcoming 2011).

${ }^{21}$ T Mitchell, 'Economists and Economics in the Twentieth Century' in G Steinmetz (ed), The Politics of Method in the Human Sciences: Positivism and Its Epistemological Others (Durham NC, Duke University Press, 2005) 126; T Mitchell, 'The Work of Economics: How a Discipline Makes its World' (2005) 66 Archive of European Sociology 297; D Greenwald (ed), Encyclopedia of Economics (New York, McGraw-Hill, 1982).
} 
still) imperial powers. Thus, even with the realisation of the promise of formal sovereign equality, nation-states could still be ordered in a hierarchy, but with GDP instead of race as the securing value. What secured this ladder was not the idea of immutable racial difference, but a promise, that states at the bottom were included within the bosom of the international community and set on a path toward joining the ranks of the chosen few 'developed' states at the top. This 'new' hierarchy was an hierarchy of desire ${ }^{22}$ structured around both a promise and a technical challenge. In this way, development immediately provided a means of ordering the world in which everyone was included on formally equal terms, but in which a hierarchy - and essentially the old hierarchy - was maintained. Development became central to what Rist has called the 'anti-colonial imperialism' of the Cold War era, ${ }^{23}$ quickly becoming the only idiom in which demands for greater material equality were issued, both inside and outside the nation-state.

Development's capture of the way poverty is understood and addressed within international law and institutions combines with the structural homologies between the two fields, such that; global and historical causes of poverty cannot be recognised within international law and institutions; and a radical separation arises between those who are understood as producers of knowledge, and those to whom that knowledge is applied. Development's centrality to international institutions also provides meaning for justice as the symbolic horizon of international law, displacing the political contestation of meaning around that term, and placing growth at the heart of institutional approaches to reducing global poverty. The combined effect is to allow

\footnotetext{
${ }^{22}$ JL Beard, The Political Economy of Desire: Law, Development and the Nation (Abingdon, Routledge-Cavendish, 2007).

${ }^{23}$ Rist, The History of Development (New Jersey, Zed Books, 1997) 75.
} 
the self interested behaviour of the North to be understood as altruism toward the South.

\section{Localising the Causes of Poverty}

Many volumes have been dedicated to the question of why some countries are poor. Several causes are proffered, both explicit and implicit, in the literature. One explanation locates the causes of poverty in the political and institutional culture of poor societies - they have corrupt elites, oppressive governments, or no formal laws and institutions. ${ }^{24}$ In another explanation, the religious and philosophical traditions that underlie poor countries' institutions are not adapted to a modern economy, and don't reward the industriousness or co-operative talents of their members; or blame is sheeted home to the absence of infrastructure, and the consequent limitations on investors and local entrepreneurs. ${ }^{25}$ Another set of explanations suggests that physical endowments are to blame; some states have been unlucky in the geographic lottery (for example, by being landlocked). ${ }^{26}$ Other analysts locate the causes of poverty in the history of slavery and colonial exploitation. ${ }^{27}$ Others focus on unfair international trade rules, and the differential impacts of the practices of some economies on others, or on the ways in which certain international lending practices have created an insurmountable debt burden for some states. ${ }^{28}$

\footnotetext{
${ }^{24}$ See eg. D North, 'Economic Performance Through Time' (1994) 84 American Economic Review 359.

${ }^{25}$ See eg. T Homer-Dixon, 'The Ingenuity Gap: Can Poor Countries Adapt to Resource Scarcity' (1995) 21 Population and Development Review 587.

${ }^{26}$ See eg. J Diamond, Guns, Germs and Steel: The Fates of Human Societies (New York, Norton, 1997); and JL Gallup, J Sachs and A Mellinger, 'Geography and Economic Development' Annual World Bank Conference on Development Economics 1998 (Washington DC, World Bank, 1999) 127.

${ }^{27}$ See eg. S Engerman and K Sokoloff, 'Colonialism, Inequality, and Long-Run Paths of Development' in A Banerjee, R Bénabou, and D Mookherjee (eds), Understanding Poverty (Oxford, Oxford University Press, 2006) 37.

${ }^{28}$ M Chossudovsky, The Globalisation of Poverty : Impacts of IMF and World Bank Reforms (New Jersey, Zed Books, 1997).
} 
These responses fall into four schematic categories: geographic causes; historical causes; international or global causes; and national or local factors particular to the poor country in question. For example the idea that poor governance and corruption explain a country's relative poverty, represent 'local' causes. That some people are culturally not adapted to capitalism similarly constitutes a 'local' cause. Causes may also overlap, so the idea that colonialism created economic structures which have hindered a country's growth - such as a heavy reliance on producing one or two commodities - is both international and historical. Or the idea that global economic structures - including unfair trade rules, and agricultural subsidies in rich countries prevent poor countries from trading their way out of poverty, signify international causes.

Undoubtedly, in relation to income poverty many of these causes operate at the same time. And yet the institutionalised discourse of development repeatedly locates the causes of poverty only in local and present causes. It does not - perhaps cannot - take account of international (or global) and historical causes of poverty. In other words, the institutionalised development story offers a very specific explanation for global poverty. Understanding the causes of poverty in this way concentrates measures to address it in projects overwhelmingly directed at the transformation of the 'developing' society and its political, legal, economic and social structures. This transformative intervention effectively aims to produce what we think of as a 'modern nation state', able to compete effectively - and to trade freely - in an essentially benign international marketplace. 
Many scholars, activists and international lawyers, particularly from the South, have critiqued this worldview. Important examples of such critique include the dependency theorists, the 'heterodox' economists and those agitating for the right to development. ${ }^{29}$ But because in the development story the international causes of poverty are simply not on the table, engagements which try to locate responsibility for global poverty at the global level, do not have any bite in the context of international law and institutions. Myriad efforts over the last sixty years have not resulted in wholesale changes to the global terms of trade, nor in good faith debt forgiveness. Instead, sixty years of development programmes have resulted in developing countries being compelled to open up more and more of themselves to the transformational interventions of the international agencies. ${ }^{30}$

Thus, over the same period as ballooning debt, the remit of the international financial institutions has expanded dramatically. The areas in which it is legal or legitimate to intervene in poor countries in the name of development has continued to widen. The conditions attached to loans have greatly proliferated, and where development institutions were once concerned with building bridges, they are now concerned with building democracy. ${ }^{31}$

\footnotetext{
${ }^{29}$ See eg. R Prebisch, 'Five Stages in My Thinking on Development' in GM Meier and D Seers (eds), Pioneers in Development (Oxford, Oxford University Press, 1984) 175; HJ Chang, Bad Samaritans: The Myth of Free Trade and the Secret History of Capitalism (New York, Bloomsbury Press, 2008); Erik Reinert, How Rich Countries Got Rich ... and Why Poor Countries Stay Poor (London, Constable, 2007); and M Bedjaoui, 'The Right to Development' in M Bedjaoui (ed), International Law: Achievement and Prospects (1991) 1177.

${ }^{30}$ See generally B Rajagopal,International Law from Below: Development, Social Movements and Third World Resistance (New York, Cambridge University Press, 2003).

${ }^{31}$ And increasingly with a gun. See P Collier, The Bottom Billion: Why the Poorest Countries are Failing and What Can Be Done About It (New York, Oxford University Press, 2008); see also William Easterly's review of the Collier book, W Easterly, 'Foreign Aid Goes Military!' in The New York Review of Books (2008) www.nybooks.com/articles/archives/2008/dec/04/foreign-aid-goes-military/.
} 
International law is implicated in the way the development discourse explains poverty by international law's own structure. Through its focus on the nation-state generally, in this context it is a structure that localises responsibility to sites within poor countries, both at the national level and increasingly within sub-national and local levels of government. ${ }^{32}$ There is no jurisdiction within international law for calling the international (or international community) to account. The effects of this characteristic of international law are particularly acute in the context of development, which is understood as an international project which starts at the 'centre'. Although international law authorises both the project and interventions to actualise it, it does not create a concomitant responsibility; there is no global responsibility, only ever local responsibility.

\section{The Separation between the Location of Knowledge Production and its Application}

International law and development are both implicated in a particular structure of knowledge, a structure we might call an 'export theory' of knowledge, in which knowledge is generated in one place - the developed world - for its consumption by others - the developing world. The structure is generated by the hierarchy produced by the narrative of development, in which some countries have attained the state of 'development' for which the others are striving. The characterisation of a state as 'developed' implies the possession of knowledge necessary to reach that state. This characterisation or naming therefore involves the investiture of authority. The promise of inclusion, understood as involving a movement up the ladder through transformation or 'development', is to be made good through the application of technical knowledge, available in the places which have already attained the desired

\footnotetext{
${ }^{32}$ L Eslava, 'Decentralization of Development and Nation-Building Today: Reconstructing Colombia from the Margins of Bogot'a' (2009) 2 The Law and Development Review 281.
} 
state. ${ }^{33}$ In international law, this produces phenomena such as Brian Simpson's 'export theory of human rights' or in development economics what Erik Reinert describes as 'the export of economic rhetoric for others. ${ }^{34}$

The explanatory content of the development story (and the localisation of the causes of poverty) combined with location of knowledge and investiture of authority in the developed world, provide a way to hold together the contradiction between the theories of development and the evidence of their results. Poor outcomes may then be blamed on the insufficiency of transformation of the developing society rather than on a flawed theory. That combination also enables the separation between the identity of the rich world as benefactor, and the rich world as a self-interested actor in the global political economy. ${ }^{35}$ The effect is to generate a frame of understanding in which the self-interest (of the rich) is equated with altruism, even when the two things are patently not commensurable. A good example of this is way the conditionalities of the World Bank and International Monetary Fund interact with both the global trading order and international financial markets.

\section{Self Interest as Altruism}

\section{Conditionalities and Global the Trading Order}

Deeply embedded in the development project is the idea that free trade will bring development. ${ }^{36}$ Resting on the theory of comparative advantage, ${ }^{37}$ development

\footnotetext{
${ }^{33}$ Beard (n 24).

${ }^{34}$ AWB Simpson, Human Rights and the End of Empire: Britain and the Genesis of the European Convention (Oxford, Oxford University Press, 2001) 347; Reinert (n 31$) 43$.

${ }^{35}$ A Orford, 'Locating the International: Military and Monetary Interventions after the Cold War' (1997) 38 Harvard International Law Journal 443.

${ }^{36}$ See eg. the Preamble to the Marrakesh Agreement Establishing the World Trade Organization opened for signature 15 April 1994, 1867 UNTS 3 (entered into force 1 January 1995).

${ }^{37}$ See D Ricardo, On the Principles of Political Economy and Taxation (London, Black Horse Court, 1817).
} 
orthodoxy asserts that countries will become richer by producing the things that they can produce most efficiently in their current condition, and by selling those things in the global marketplace. In theoretical terms this remains true even when some countries have nothing which they make the most efficiently in absolute terms (in other words when other countries produce everything more efficiently than they do). This is because the rational calculation of 'opportunity cost' ensures that the others will produce what they are absolutely best at in domestic terms, rather than just comparatively better at in global terms. ${ }^{38}$

Heterodox economists such as Ha-Joon Chang, Dani Rodrik and Eric Reinert question this orthodoxy. They expose the recipe of free trade as the path to wealth as both historically inaccurate and theoretically flawed. According to their analyses, the theory of comparative advantage on which free trade is founded, is focused solely on short-term gains, and can be justified only if one accepts the global status quo, a state of affairs which implies the continued under-development of poor countries. ${ }^{39}$ This is directly in conflict with the orthodoxy that free trade will bring development. Historically speaking, these thinkers argue, rich countries became rich by following precisely the opposite of the policies the international development institutions such as the International Monetary Fund and World Bank impose upon borrowing states. Famously, according to Chang, the rich countries have enriched themselves, and, through international laws and institutions, including 'developmental' conditionalities, have 'kicked away the ladder' so that poor countries are likely to remain in poverty if they play by the rules. ${ }^{40}$

\footnotetext{
${ }^{38}$ Reinert (n 31) 301.

39 ibid 304.

${ }^{40}$ H Chang, Kicking Away the Ladder: Development Strategy in Historical Perspective (London, Anthem Press, 2003).
} 
But such explanations, which locate the causes of poverty in part in the international sphere, cannot be heard by the institutionalised discourse of development. Despite the historical, theoretical and economic critiques of the heterodox economists, the theory that free trade will bring development is resilient, and remains dominant within international instititutions. ${ }^{41}$ The result of this dominance is that a great deal of developmental intervention is directed at restructuring the economies of poor countries as though they were participants in a global free market. This includes using the mechanism of conditionality to force poor countries to remove barriers to trade, including tariffs and subsidies, allow money to move freely across borders, to orient production toward export and to allow foreign direct investment. This coercive restructuring of state economies on the basis that free trade brings development, imposed 'as if' there were actually an essentially benign global market-place, takes place in the context of a global trading order which is anything but free. Given the real conditions of the global market, the policies prescribed are positively toxic for most poor countries.

Critiques are legion. Philosopher Thomas Pogge, for instance, points out that there is no such thing as free trade. Even as rich countries promise trade-led development, he argues, current rules favour rich countries. - by allowing them to protect their markets and subsidise exports through quotas, tariffs, anti-dumping duties, export credits and subsidies to domestic producers. ${ }^{42}$ To sketch the financial magnitude of these

\footnotetext{
${ }^{41}$ World Bank, 'Global Challenges: Global Public Goods' (2010) http://go.worldbank.org/7XUN86PV10; WTO, 'Understanding the WTO: Basics' (2011) www.wto.org/english/thewto e/whatis e/tif e/fact3 e.htm; International Monetary Fund, 'What We Do' (2011) http://www.imf.org/external/about/whatwedo.htm.

${ }^{42} \mathrm{~T}$ Pogge, 'Recognized and Violated by International Law: The Human Rights of the Global Poor' (2005) 18 Leiden Journal of International Law 771.
} 
subsidies, it is salutary to compare them to aid flows. Former Chief Economist of the World Bank, Nicholas Stern, estimated that in 2002, rich countries spent about $\$ 300$ billion on export subsidies for agricultural products alone, roughly 6 times their total development aid. $^{43}$ Cows in Europe famously receive annual subsidies of around $\$ 900$ each, and in Japan of about $\$ 2,700$ each - far above the annual income of most human beings, let alone the aid budget per capita. ${ }^{44}$ Poor countries cannot match these subsidies, not only because they often cannot afford to, but also because they are prohibited from doing so by international law. This prohibition arises both from trade negotiations in the context of unequal bargaining power, ${ }^{45}$ but perhaps more insidiously, from conditionalities contained in international agreements with the World Bank and the IMF. ${ }^{46}$

As well as protecting their own markets and producers, on the other side of the equation, rich countries manage their input costs through the use of 'escalating tariffs'. These are scales which apply low tariffs to raw materials - starting with no tariffs at all on those raw materials which can't be grown or found in rich countries and which then raise the tariffs sharply with each step up the value chain. This ensures cheap raw materials for rich countries, whilst undermining manufacturing and employment in poor countries. Hence Ghana and Cote D'Ivoire are confined to exporting unprocessed cocoa beans, Uganda and Kenya to raw coffee beans, Mali and

\footnotetext{
${ }^{43} \mathrm{~N}$ Stern, 'Dynamic Development: Innovation and Inclusion' (Munich Lectures in Economics, Munich, 19 November 2002) http://team.univparis1.fr/teamperso/page/files/BM\%20Nicholas\%20Stern.pdf.

${ }^{44}$ Development assistance in the same year was $\$ 8$ to each sub-Saharan African from Europe, or $\$ 1.47$ to each African from Japan. M Wolf, Why Globalization Works (New Haven, Yale University Press, 2005) 215.

${ }^{45}$ Pogge attributes the causes to the inequalities in bargaining power arising from the fact that countries 'with only $15.5 \%$ of the world's population ... have $80.4 \%$ of the world's income and can therefore exact a high price for access to ... markets'. Pogge (n 44) 724. Pogge is relying for these figures on World Bank, World Development Report 2005: A Better Investment Climate for Everyone (New York, Oxford University Press, 2005) 257.

${ }^{46}$ Chossudovsky (n 30) 61; Life and Debt (Directed by Stephanie Black, Tuff Hong Pictures, 2001).
} 
Burkina Faso to raw cotton. ${ }^{47}$ There are many more examples demonstrating how, despite the rhetoric, the current trade rules are not only not free, but in fact create capital flows and lost opportunities that hurt poor countries in ways which simply dwarf foreign aid flows. ${ }^{48}$ Criticisms about the unfair trading practices of rich states also come from the other end of the political spectrum. Financial journalist and defender of (real) free trade, Martin Wolf for instance denounces the treatment accorded to the poorest states in the trading regime as 'a disgrace'. ${ }^{49}$ Wolf catalogues a litany of what he calls 'obscenities' arising from the EU's Common Agricultural Policy, US Cotton subsidies, Japanese farming subsidies and the licence payments demanded through the TRIPS agreement inter alia. ${ }^{50}$

Institutions such as the World Bank understand the way that policies like agricultural subsidies hurt poor countries, but because it has no jurisdiction over rich countries, it can't do anything about them. What is more curious, is that even though institutions such as the World Bank are limited in this way, they continue both to espouse the ideology of free trade, and to impose and support conditions which oblige poor countries to open their markets and liberalise their investment rules. Recommending these policies in a perfect world is already highly contested by the heterodox economists such as Chang, Rodrik and Reinert. Enforcing those policies in the global economic conditions of the real world could at best, be the triumph of hope over

\footnotetext{
${ }^{47}$ Stern (n 45) 25. In another speech, Stern estimates that full elimination of agricultural protection and production subsidies in rich countries would raise agricultural and food exports from low to middle income countries by $24 \%$ and total annual rural income in these areas by about $\$ 60$ billion (about three quarters of the global poor live in such rural areas). Pogge (n 44) fn 19.

${ }^{48}$ Pogge (n 44) 725.

${ }^{49}$ Wolf (n 46) 218.

${ }^{50}$ ibid 215. He also cites escalating, or 'progressive' tariffs as grossly unfair, giving the example of Bangladeshi imports to the US, producing tariff payments of \$331million in 2001. Compare this to France, who exports to the US, producing tariff revenues of the same amount. But the total imports from France were 13 times larger. This shows how tariffs apply at the highest level on products poor countries tend to export.
} 
experience, and in particular, over fifty years of experience of the immiseration these policies cause.

The outcome, however, is to reinforce a trading system heavily skewed toward the interests of the rich world, in which borders of poor countries are opened to subsidised products from the North, destroying local industries which cannot compete with artificially cheap imports and in which poor countries are penalised for adding value to raw materials in ways which might potentially bring about industrialisation. These inequities are effected in part through international interventions in the name of 'development'. The theoretical foundation that free trade brings development is supported by a particular narrative of development in which the West is characterised as essentially benign. The theory, untainted by critiques which would question that characterisation in the context of the global trading order, justifies the imposition on the South of legally enforceable conditions which open borders and prevent defensive policy making. The institutions which impose those conditions retain their putative legitimacy on the implicit reliance on the export theory of knowledge and the split between the identity of the West as benefactor and as predator are bifurcated. The self interested behaviour of rich countries can be present as altruism because of the institutionalised development project.

\section{Conditionality and finance}

The relationship between conditionality and the global financial system is another example of the way in which the institutionalised development project enables self interest to be understood as altruism. Debt forgiveness campaign Jubilee 2000 estimates that over one hundred countries need debt cancellation to enable them to meet their people's basic needs without taxing those below an 'ethical poverty line' of 
three dollars a day. They point to the example of Kenya, which in its 2005/2006 budget, spent more on debt repayments than on the combined total expenditure on water, health, agriculture, roads, transport and finance. ${ }^{51}$

While the debt question is complex and some debt is legitimate, there is a great deal of Third World debt which is illegitimate, having arisen through irresponsible lending during the oil boom in the 1960s and 1970s, often for strategic defence reasons connected to the Cold War. Many of the projects funded were misconceived or failed. Many of the loans were to corrupt and/or racist governments known to be such by the lenders. Often everyone involved in the lending knew that repayment was never likely. ${ }^{52}$ Combined with these problems of legitimacy, commodity prices declined dramatically over the same period. Most loans were denominated in 'hard' currencies like the dollar, exposing borrowers to risks from matters over which they have no control, such as US dollar interest rate rises and currency volatility. ${ }^{53}$

In the aftermath of the repayment crises of the 1980's and beyond, the conditionality mechanism of the international financial institutions has typically been used to restructure poor economies primarily to ensure loan repayment and the stability of the international banking system. As a result, debt servicing is made possible by cuts to public spending in health, education and food subsidies. ${ }^{54}$ And as we saw above, continued funding from those institutions is conditioned on poor countries opening

\footnotetext{
${ }^{51}$ Jubilee Debt Campaign, 'Why should we drop the debt?' www.jubileedebtcampaign.org.uk $/ 1 \% 20 \mathrm{Why} \% 20$ should $\% 20 \mathrm{we} \% 20 \mathrm{drop} \% 20$ the $\% 20 \mathrm{debt} \% 3 \mathrm{~F}+2675 . \mathrm{t}$ $\frac{\mathrm{Wl}}{52}$.

${ }^{52}$ R Peet, Unholy Trinity: The IMF, World Bank and WTO (London, Zedbooks, 2003) 78.

${ }^{53}$ ibid 76.

${ }^{54} \mathrm{~J}$ Walton and D Seddon, Free Markets and Food Riots: The Politics of Global Adjustment (Oxford, Blackwell, 1994).
} 
their markets to imports (often subsidised) from rich countries and to unrestricted foreign direct investment.

This pattern illustrates how the existence of Third World Debt provides a very effective legal or juridified mechanism which transfers wealth and risk in opposite directions. In the commercial lending market, the lender carries the risk of the borrower not being able to repay the loan. In the situation of Third World Debt, the lender is often acquitted of the full consequences of imprudent lending through the interventions of the international financial institutions. This institutional intervention happens even as those same institutions extol the virtues of market disciplines for their (poor) clients. Risk is therefore transferred from those who can most afford it rich countries and banks in rich countries - to the people of the Third World, who can least afford it. Wealth is transferred in the opposite direction, from the people who can least afford it - the citizens of Third World countries who need whatever public services their state can afford - to rich countries, their banks, and the shareholders of those banks.

\section{The Limits to Growth and the place of Justice}

The final problem with development's capture of how we understand questions of material well being within international law and institutions is in the way it places growth at the heart of institutional approaches to reducing global poverty. This emplacement displaces contestation around the meaning of justice as the symbolic horizon of international law. ${ }^{55}$ Because GDP was the lynchpin of the global order newly structured around a promise, the key to that promise - economic growth - had

\footnotetext{
${ }^{55}$ Pahuja (n 22).
} 
to lie at the heart of the project: economic growth was - and remains - the secret beating heart of the development story.

According to the theory of economic growth, the rising tide lifts all boats. In other words, by increasing overall wealth, even if the rich get richer, some of the wealth is meant to eventually 'trickle down' to the poor. This idea took hold, and captured the zeitgeist. It was quickly embraced by people of all political and geo-political stripes. Communism, which was equally if not more 'developmental' than the First World, also embraced the need for growth as axiomatic. Hence, even if there was fierce contestation around how growth should be achieved, growth as the objective of development was immediately enthroned.

As time wore on and people began to realise the inadequacy of national income as the measure for development success, other definitions of development, and crucially, other measures of development, were developed - perhaps most famously the Human Development Index devised by Mahbub U1 Haq and the UNDP in the 1990s. This measure adds life expectancy and literacy to GDP to come up with a single figure index to indicate development. Amartya Sen, too, is famous for reconceptualising development as freedom, using what he calls the 'capabilities approach'.

But even the most famous reconceptualisations, such as Sen's, still have economic growth at their heart. ${ }^{56}$ The shift has not been away from growth as the determinant, but towards growth 'plus'. International law and institutions have stayed very much

\footnotetext{
${ }^{56}$ Pahuja (n 22) 222; B Chimni, (2008) 'The Sen Conception of Development and Contemporary International Law Discourse: Some Parallels' 1 Law and Development Review www.bepress.com/ldr/vol1/iss1/art2;U Baxi, The Future of Human Rights (Oxford: Oxford University Press, 2002).
} 
within the paradigm - for example the World Bank's most recent response to criticisms about the inadequacy of growth has been to shift to inclusive growth. ${ }^{57}$ Many NGOs have tried to modify the formula by demanding what they call 'pro-poor growth'. 58

The G20's latest summit declaration even reverses the emphasis, 'recognis[ing] that 2010 marks an important year for the MDG's, and reaffirm[ing] the commitment to assist the poorest countries', but situating that reaffirmation within, and dependent on, the main game of continued global growth: ‘ [...n]arrowing the development gap and reducing poverty are integral to our broader objective of achieving strong, sustainable and balanced growth and ensuring a more robust and resilient global economy for all. ${ }^{59}$ Even within what are known as 'rights based approaches' to development, growth is still the engine of development, and therefore the main way to alleviate global poverty. Within liberalism, growth is understood as an alternative to redistribution as the way to address poverty. ${ }^{60}$

Leaving aside the well known critiques about the social limits to growth and its ambiguous relation with the problem of inequality, a key problem with using gross national growth as the measure of the improvement of life is that it has the effect of setting the environment and development against each other. Within the vocabulary of international law, it seems impossible to be both for the environment, and for

\footnotetext{
${ }^{57}$ World Bank, 'What is Inclusive Growth?' (2009) http://siteresources.worldbank.org/INTDEBTDEPT/Resources/4689801218567884549/WhatIsInclusiveGrowth20081230.pdf.

58 M Ravallion, 'Pro-Poor Growth: A Primer' (World Bank Policy Research Working Paper No. 3242, 2004) http://web.usal.es/ bustillo/RavallionPPGPrimer.pdf.

${ }^{59}$ The G-20 Toronto Summit Declaration June $26-27$ 2010, para 46 www.g20.org/Documents/g20 declaration_en.pdf.

${ }^{60}$ A Ellis and K Kumar, 'Dilemmas of Liberal Democracies: Studies in Fred Hirsch's Social limits to Growth' (London, Tavistock Publications, 1983) 3.
} 
economic justice. Indeed, historically, development and environment have often been antagonistic discourses. Common wisdom has typically suggested that we need to tackle poverty first, and 'clean up' later. People speak of an environmental 'Kuznets curve' in which cities undergoing rapid development peak at a certain level of pollution and then quickly improve as the society gets richer. ${ }^{61}$ While that might relevant for ambient environmental degradation such as air quality and the pollution of waterways, it is becoming clear that there are some things which cannot be reversed. Carbon emissions, for example, just keep increasing. Many of the world's species are facing imminent extinction, there is a huge loss in plant biodiversity, and the oceans are being emptied of fish. None of these is reversible.

The environmental facts call into question a development promise based on an infinitely expanding pie. An emphasis on growth is being maintained in the face of an overwhelming body of scientific evidence that suggests that we are already using 1.5 planets. ${ }^{62}$ If everyone on earth lived with the ecological footprint of an average (US) American, we would need approximately 5 planets to sustain the current population of the earth. ${ }^{63}$ In the face of this, it is difficult to see how a good faith promise of any kind of equivalence could be made. Given that the earth could sustain a population of around 1.8 billion people living at the current consumption levels of an average person in a high-income country, as opposed to the almost 7 billion we currently have with vastly disparate consumption levels, what is it exactly, that development is promising?

\footnotetext{
${ }^{61}$ D Stern, 'The Environmental Kuznets Curve' (International Society for Ecological Economics Internet Encyclopaedia of Ecological Economics, June 2003) http://www.ecoeco.org/pdf/stern.pdf. ${ }^{62}$ Global Footprint Network, 'World Footprint: Do We Fit on the Planet?' (2010) www.footprintnetwork.org/en/index.php/GFN/page/world_footprint.

${ }^{63}$ WWF International, 'Living Planet Report 2010: Biodiversity, Biocapacity and Development' (2010) http://assets.panda.org/downloads/lpr2010.pdf.
} 
The implications of this fact have been recognised in the turn by states and international institutions to the promotion of 'sustainable development'. At its core, sustainable development means 'development that meets the needs of the present without compromising the ability of future generations to meet their own needs' ${ }^{64}$ In theory, sustainable development understands that three intersecting spheres of society, environment and economy must complement each other if development is to be sustainable. The goal then is to find the 'sweet spot', or point of overlap, between these three distinct spheres. ${ }^{65}$

However, in practice, without a fundamental redefinition of each distinct sphere, the 'sweet spot' is a myth. Economic growth has been difficult to dislodge from the heart of the development project, and sustainable development is overtly directed towards sustaining growth-based development, rather than sustaining the social, natural and political environment in which it takes place. ${ }^{66}$ And yet, even that more circumscribed horizon may not be achievable. Whether through the idea that technology will enable growing consumption through 'green growth', ${ }^{67}$ or that we will 'clean up' after development has taken place, or that growth should be 'inclusive' or 'pro-poor', ${ }^{68}$ even on its own terms, sustainable development is at best capable of producing less unsustainable development.

\footnotetext{
${ }^{64}$ World Commission on Environment and Development, 'Our Common Future' (Annex to UN General Assembly Document A/42/427, 1987) http://www.worldinbalance.net/pdf/1987brundtland.pdf.

${ }^{65}$ B Hopwood, M Mellor and G O’Brien, 'Sustainable Development: Mapping Different Approaches' (2005) 13 Sustainable Development 38.

${ }^{66}$ ibid.

${ }^{67}$ J Baskin, 'Is Sustainable Development Sustainable?' (Unpublished paper presented to Asian Development Bank, April 2011).

${ }^{68}$ Ravallion (n 60).
} 
Within international approaches to global poverty alleviation, development is both process and horizon. It is both what we are trying to achieve, and the way we achieve it. It is both the building of a bridge, and the abstract promise of a better life. It is both the implementation of a law reform project in the Pacific Islands, and (as Beard has put it) 'a numinous yearning for a better life'. ${ }^{69}$ Because of this character as both process and horizon, development's relation to international law displaces the more open concept of justice which international law arguably promises as its horizon. ${ }^{70}$ The idea that we can reduce poverty without affecting the distribution or the accumulation of wealth is nonsense. But by centring the development story on growth, the promise to the poor is that they must invest their hopes of improving their material well being, in increases in the overall size of the pie. This is meant to increase the size of each crumb proportionately. That this also increases the size of the rich countries' slice of the pie, or of the rich people in poor countries, it is simply a collateral benefit of doing good for the poor. Here, self-interest and altruism are seen as made entirely commensurable by the concept of growth. Of course, according to this logic, there can be no question of the pie being shared differently, or really even countenancing the idea that the pie might be of a finite size.

This depoliticisation, by growth, of the meaning of justice interacts with the structural homology between development and international law to consistently deradicalise current thinking on the best ways to address the question of global poverty. Because of development's centrality and the explanation of global poverty it carries with it, international legal solutions to global poverty (including human rights based solutions) do not have any bite between nations, but only within them. In other words,

\footnotetext{
${ }^{69}$ Beard (n 24) 2.

${ }^{70}$ Pahuja (n 22).
} 
it is difficult, if not impossible, to use international law against the international. The question of how we share the earth is removed from the table. Economic growth defers the question of distribution through an emphasis on a future horizon. International law's toothlessness means that calls for a more equitable global distribution of wealth have no bite. ${ }^{71}$

\section{Conclusion}

In his play about the martyrdom of the Bishop Thomas Beckett, T.S Eliot writes

The last temptation is the greatest treason:

To do the right deed for the wrong reason.

The line is meant to explain Beckett's realisation that his willingness to be sacrificed was wrongly motivated by the martyrdom which would come from it, rather than selfsacrifice without glory. Legal evaluation generally reverses that judgment and concentrates on the deed, not the reason. This reversal is necessary for balancing the interests of the well intentioned actor with the protection of the person who is the subject of that action.

In the context of international law and development though, that the judgment is reversed again. Interventions directed at bringing about 'development' are assessed primarily by reference to the intentions of the 'developer' rather than the effect of those actions on the 'developing'. This is exacerbated by the way accountability measures usually involve accountability to the donors, not to the subjects of

\footnotetext{
${ }^{71}$ A symptomatic case of this is when activists call for (legally binding) human rights, the way the structure of international law works means that those rights are directed at the nation-state within which individuals are situated, and its municipal laws. They cannot be claimed, for example, against former imperial powers, or against rich states and their subsidies, nor even against the international financial institutions. Similarly calls to link labour standards to international trade would piggy back on the enforcement mechanisms of the trade regime to require poor states to respect human rights or labour standards - and incidentally privilege products from rich countries - surely human rights in their most imperial guise?
} 
developmental interventions. In other words, we in the rich world, assess ourselves, and base that assessment on our intentions.

This effect is made possible by the explanatory narrative development offers for the causes of poverty, and for the investiture of knowledge production in the rich world. The effect is ratified in law through its allocation of responsibility to the nation-state. The cover of development shrouds with altruism, acts which work in the West's own self interest. Often, the politics of good intentions can provide a cover for poor outcomes: even though we may have done the wrong things, we are assessed on the reason we did them, not on their effects.

However, although good intentions might be morally relevant to the individual, when they are combined with the force of law, those intentions must be tempered by the responsibilities of power, even more so in the case of institutions. The responsibility of power is not answered by reference to intentions. Power brings us back to the question of authority, and the practices which law authorises. Shaikh's 'benevolence of empire' suggests that although it is probably natural to think that one's own way of life is the best, it is quite another thing to have both the desire and the power to impose that way of life on others, whether out of self interest or altruism, or some combination of the two. In intervening to bring about the conditions of modernity, even with the best intentions, the West is effectively arrogating to itself, the right to develop the rest.

Even if we understand that arrogation as a duty, rather than a right, it is difficult to see how the development promise can be made good given the limits to growth. One way 
to proceed would simply be to recognise the impossibility of the promise and abandon it, fortifying the rich world with increasing violence and surveillance against the clamour to 'get in'. Some say that a version of that is already happening. But arguably we do not need such a dystopic vision of the future if we accept that what thinking about poverty and the environment together really means is that we need to re-think how we share the earth and how this sharing is to occur through international law.

The enormous political solidarity demonstrated at the recent protests in Toronto at the 2010 G20 summit, and indeed at every multi-lateral economic summit meeting since Seattle in 1999, shows that people do care about the suffering of strangers in far-away places, and about the state of the planet. But to date, the development project has captured a great deal of that energy for justice, and channelled it in ways which have shown themselves to be unlikely to alleviate global poverty. The visibly diminishing capacity of the earth to sustain us might provide the impelling political force we need to make a shift away from development's certainties. But even if Pogge is right in suggesting that it is easier to make good laws than good men, ${ }^{72}$ we cannot simply argue for the reform of laws and institutions which hurt the poor, but we also need to think carefully about the institutional structures which support the production of those unfair laws in the first place.

Both development and international law are the children of imperialism, and carry the legacy of that inheritance. And they are both institutionalised structures of knowledge with ready armies of experts bearing solutions to the world's problems. The big

\footnotetext{
72 'morally successful rules are so much easier to sustain than morally successful conduct'. T Pogge, 'Severe Poverty as a Human Rights Violation' in T Pogge (ed), Freedom from Poverty as a Human Right: Who Owes What to the Very Poor? (New York, UNESCO and Oxford University Press, 2007) 11,26 .
} 
differences though, are that law has a formal structure, and its promised horizon is the politically contestable notion of justice. Only by rejecting law's instrumentalisation within the development project, and by refusing the replacement of the horizon of justice with the horizon of development might there be a chance to harness the widespread faith in international law and human rights in ways which save it for the poor, and which breathe life back into its powerful symbolic promise for... most of the world. ${ }^{73}$

\footnotetext{
${ }^{73} \mathrm{P}$ Chatterjee, The Politics of the Governed: Reflections on Popular Politics in Most of the World (New York, Columbia University Press, 2004) 3.
} 


\section{University Library}

\section{- M M N E R VA A gateway to Melbourne's research publications}

Minerva Access is the Institutional Repository of The University of Melbourne

Author/s:

Pahuja, S

Title:

Global Poverty and the Politics of Good Intentions

Date:

2014

Citation:

Pahuja, S. (2014). Global Poverty and the Politics of Good Intentions. Buchanan, R (Ed.). Zumbansen, P (Ed.). Law in Transition: Human Rights, Development and Transitional Justice, Law in Transition: Human Rights, Development and Transitional Justice, (1), pp.31-48. Hart Publishing.

Persistent Link:

http://hdl.handle.net/11343/251844 